\title{
Narokkong
}

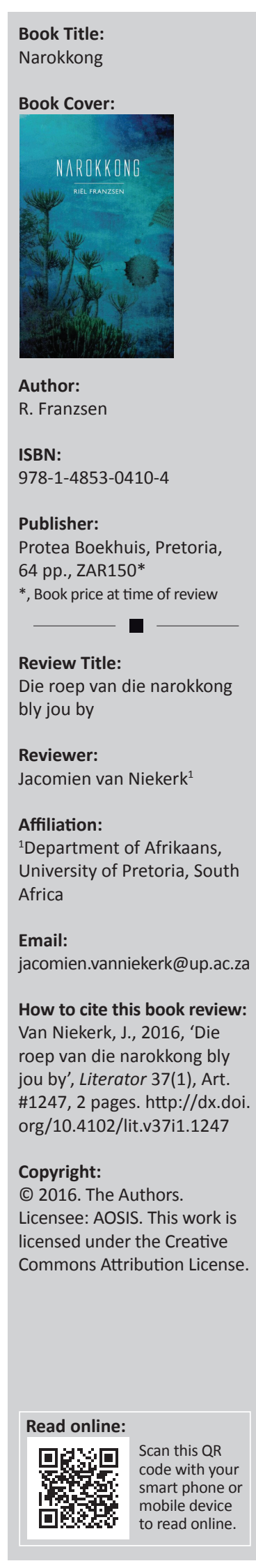

\section{Die roep van die narokkong bly jou by}

Narokkong, die debuutbundel van Riël Franzsen, is geskoei op 'n (na my wete) oorspronklike konsep in die Afrikaanse poësie, naamlik die outisme van die spreker se seun.

Elke leser moet self oordeel of hierdie nou omvang van die bundel beperkend is en of Narokkong juis as 'n geslaagde 'eenheidsbundel' bestempel kan word. Die impak van outisme op sowel die seun as sy ouers word sistematies geskets, onder andere in 'Outisme I' (bl. 16):

Ouers wonder verwilderd
maar die outis,
wild en verwonderd,
vra:
Waar is ek? Waar is ek?
Hoe dans mens in sirkels
in hierdie vierkantige plek?

Die gegewe van die outistiese kind word deur 'n intertekstuele laag aangevul. In die gedig 'Narokkong' (bl. 14) word die titel van die bundel verklaar met behulp van 'n verwysing na 'n skets deur Sangiro getitel 'Koors'. Volgens die omdigting van hierdie skets is die narokkong 'n nagvoël wat in die top van 'n naboom in Kenia leef en selfs die plaaslike Masai weet nie waarvan die voël leef nie. In die slotstrofe (bl. 14) eien die spreker hierdie byna mitiese voël toe as 'n onheilsvoël wat outisme veral onder seuns veroorsaak:

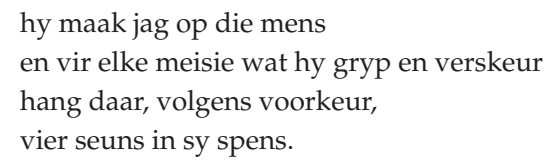

Daar is egter reeds in 'Diagnose' (bl. 11) sprake van "n nagvoël se geskree' wat suggereer dat die gedigte ook buite hulle volgorde in die bundel gelees sou kon word. In die gedig 'Timbavati' (bl. 33) word dit duidelik dat D.J. Opperman in sy gedig 'Koggelbos' (uit Komas uit ' $n$ bamboesstok) met Sangiro in gesprek getree het. In dié gedig speel Opperman met die eendersheid van 'naboom' en 'naboots' en die 'narokkong' word 'n koggelende voël. In Narokkong is daar telkens sprake van outisme as 'n koggelende herinnering wat feitlik elke alledaagse aktiwiteit besmet. Omvattende kennis van voëls spreek uit die feit dat Franzsen die woord narokensis in die wetenskaplike naam vir die 'Oostelike heuningwyser' (bl. 43) nagespeur het. Die gedig bevat, teen die leser se aanvanklike verwagting in, 'n speelse element waarin daar van een assosiasie na 'n ander gespring kan word sonder om by droë feite vas te steek. Dit is duidelik dat die heuningwyser in dié gedig nie 'n nagvoël is nie, maar die wyse waarop die voël die herder in die gedig bedrieg, 'verby die bynes' na die 'naboomnes', verwoord knap die verwarring waaraan die spreker in Narokkong sowel as die outistiese kind gereeld onderwerp word. Al die verwysings na die 'nagvoël' of 'Swartoog' (soos dit ook genoem word) in die bundel bewerk eenheid en dit is 'n beeld wat die leser agterna bybly.

Die bundel begin met 'Vrugwater' (bl. 9) en ontvou verder as 'n taamlik liniêre maar nie streng-chronologiese verslag van die lewe van 'n outistiese seun. Ervarings progresseer van '[h]ospitaalgange'(bl. 22), operasies en kinderpsigiaters ('Poppekas', bl. 24-25), ontstellende angsaanvalle tuis (bl. 27, 28) tot opname in 'Denmar' (bl. 29). Wanneer medikasie doeltreffend is, is daar weer 'Remissie' (bl. 35) en 'Ewewig' (bl. 36). Daar is sprake van verblyf in 'n '[t]ehuis vir outiste' (bl. 51), maar met sy mondigwording is die seun nog onmiskenbaar in sy ouers se sorg ('Beseringstyd' [bl. 54] en 'Een-en-twintig' [bl. 61]).

In 'Outisme II' (bl. 40) word gevra wanneer die twintigste-eeuse term 'outis' vir die eerste keer in Afrikaanse woordeboeke opgeneem is. Die toon van die eerste en derde strofes is tong-indie-kies, maar die lys woorde in die tweede strofe ('onregeerbaar', 'uitgeslote', 'eiesinnig', 
ensovoorts) is een van die talle plekke in die bundel waar dit blyk hoe moeilik die spreker hom met sy kind se toestand vereenselwig. Soms word hierdie aspek verbeeldingloos geartikuleer, byvoorbeeld in 'Kringloop' (bl. 17): 'Hoekom, God, hoekom?'. Ook in die slotgedig van die bundel is daar die minder effektiewe uitroep 'Contra naturam, o Heer', maar die treffende wyse waarop die verhaal van Abraham en Isak in die laaste vier reëls omvorm word, red die gedig.

Ander gedigte kry dit ook reg om wrang humor en bitter ontnugtering te balanseer: soms in 'n titel soos 'Hippokrates het sy hande vol' (bl. 23), of in die bespiegeling in 'Prototipe' dat die Skepping van God se outisme getuig (bl. 56).
Die taalspel in 'Kunsgeskiedenis' (bl. 48) - 'waarom Vermeer vra?' - is dalk 'n bietjie té slim, maar die voorafgaande strofes waarin die (on)vermoë verken word van sekere kunswerke of -strominge om met die outistiese kind te resoneer, is geslaagd.

Met sy kort gedigte en beperkte temas is Narokkong nie 'n ambisieuse bundel nie. Tog maak dit 'n positiewe indruk aangesien die bundel deeglik afgewerk is. Elke gedig lewer 'n sinvolle bydrae tot die bundel as geheel en daar is geen rafels nie. Die gedigte is toeganklik en onbetwyfelbaar gevoelvol, met genoeg tegniese vaardigheid om die lees van Narokkong die moeite werd te maak. 